\title{
Pengaruh Kompetensi Manajerial dan Kewirausahaan Kepala Sekolah Dalam Meningkatkan Mutu Layanan Akademik di Kabupaten Ciamis
}

\author{
Lili Abdullah Rozak, Sumarto, Diding Nurdin, Eka Prihatin \\ Universitas Pendidikan Indonesia, Bandung, Jawa Barat, Indonesia \\ liliabdullah1976@gmail.com
}

Naskah diterima tanggal 02/03/2021, direvisi akhir tanggal 14/06/2021, disetujui tanggal 03/08/2021

\begin{abstract}
Abstrak
Tujuan penelitian ini adalah menjelaskan bagaimana pengaruh kompetensi manajerial dan kompetensi kewirausahaan kepala Sekolah Menengah Pertama Negeri terhadap mutu layanan akademik yang didukung dari hasil wawancara. Mutu layanan akademik perlu ditingkatkan karena pada prestasi akademik siswa, kekurangan jumlah guru serta sarana dan prasarana belajar. Data di dapatkan dari 80 Sekolah Menengah Pertama Negeri di Kabupaten Ciamis dengan jumlah sampel sebanyak 322. Sementara wawancara dilakukan kepada kepala sekolah dan pengelola sekolah di dalamnya. Data dianalisa dengan menggunakan regresi linear ganda untuk melihat seberapa besar pengaruh kompetensi manajerial $\left(\mathrm{X}_{1}\right)$ dan kewirausahaan $\left(\mathrm{X}_{2}\right)$ terhadap terhadap mutu layanan akademik $(\mathrm{Y})$. Hasil tersebut didukung dengan hasil wawancara. Dari hasil analisa data menunjukan bahwa kompetensi kompetensi manajerial $\left(\mathrm{X}_{1}\right)$ dan kewirausahaan $\left(\mathrm{X}_{2}\right)$ berpengaruh terhadap mutu layanan akademik (Y). Penelitian sangat berguna untuk para peneliti sebagai referensi serta kepala sekolah dalam mengambil keputusan dalam manajerial dan kewirausahaan. Adapun yang lebih penting adalah bagaimana mutu layanan yang diberikan oleh pemerintah melalui kepala sekolah mampu ditingkatkan dalam rangka memenuhi daya saing global di tingkat nasional maupun internasional.
\end{abstract}

Kata Kunci: Kepala Sekolah, Mutu Layanan Akademik, Kompetensi Manajerial, Kompetensi Kewirausahaan

\begin{abstract}
The purpose of this study is to explain the influence of Public Secondary School Principals on managerial and entrepreneurial competence on the quality of academic services and supported by the results of interviews and documentation studies. Academic quality needs to be improved because of the student's academic skills, the lack of teachers, and the learning facilities and infrastructure in the school. Data were obtained from 80 Public Secondary schools in Ciamis Regency as many as 322 teachers. Data analysis using multiple linear regression to see how much influence managerial competence (X1) and entrepreneurship (X2) on the quality of academic services (Y). These results are supported by the results of the interviews. The results of data analysis show that managerial competence (XI) and entrepreneurship (X2) affect the quality of academic services (Y). Research is very useful for researchers as a reference as well as principals in making managerial and entrepreneurial decisions. What is more important is how the quality provided by principals is able to improve the framework to meet global competitiveness at the national and international levels
\end{abstract}

Keywords: Principal, Academic Service Quality, Managerial Competence, Entrepreneurial Competence

How to cite (APA Style) : Rozak, L A., Sumarto., Nurdin, D., \& Prihatin, E. (2021). Pengaruh Kompetensi Manajerial dan Kewirausahaan Kepala Sekolah Dalam Meningkatkan Mutu Layanan Akademik di Kabupaten Ciamis. Jurnal Penelitian Pendidikan, 21 (2), 2021. 98-111. doi: https://doi.org/10.17509/jpp.v21i2.37241

\section{PENDAHULUAN}

Pendidikan sangat penting untuk memberikan bekal bagi anak bangsa dalam menjamin hidupnya di masa depan. Seperti yang disampaikan Hafees (2017) bahwa pendidikan salah satu bagian yang sangat mendominasi dalam perannya dalam menentukan keadaan bangsa dan negara di masa yang akan datang. Keterampilan pendidikan dasar seperti membaca dan menulis berdasarkan hasil penelitian ternyata dapat meningkatkan pendapatan seseorang hingga 10\% dan dapat bertindak sebagai senjata sempurna bagi setiap individu yang membantu memberantas secara internasional dari kemiskinan dan kelaparan (Madani, 2019). 
Menurut Sallis (2012) tentang definisi mutu adalah menyesuaikan diri dengan spesifikasi. Spesifikasi yang dimaksud adalah spesifikasi yang diberikan atau diarahkan oleh pemerintah keterkaitan dengan komponen-komponen pendidikan yang harus dimiliki oleh sekolah. Organisasi atau lembaga yang menganut konsep Total Quality Management (TQM) melihat mutu sebagai sesuatu yang didefinisikan oleh para konsumen mereka (peserta didik/orang tua dan masyarakat) (Sallis E., 2012).

Kualitas pendidikan tercerminkan pada berbagai tanda salah satunya adalah nilai ujian yang diperoleh siswa (Madani, 2019 hlm.100). Layanan pendidikan (dalam hal ini adalah layanan akademik) yang berkualitas tentunya menjadi faktor penting yang menjadikan masyarakat akan percaya menyekolahkan anak-anaknya pada sekolah tersebut. Mulyana (2015) menjelaskan bahwa manajemen mutu akademik di sekolah ditentukan oleh beberapa faktor yaitu bagaimana peran kepala sekolah sebagai seorang pemimpin dan profesionalitas guru yang ditentukan oleh kompetensi-kompetensi yang dimiliki, serta partisipasi masyarakat melalui orang tua siswa dan komite sekolah. Latar belakang dan tingkat pendidikan orang tua memberikan peran yang penting dalam kualitas pendidikan anak-anaknya (Madani, 2019). Sedangkan kompetensi kepala sekolah yang dimaksud menurut Peraturan Menteri Pendidikan dan Kebudayaan nomor 13 Tahun 2007 salah satunya adalah Kompetensi Kepribadian, Kompetensi Supervisi dan Komptensi Manajerial.

Permasalahan muncul dari pelaksanaan Ujian Nasional yang diselenggarakan pada tahun 2019, peserta didik dapat lulus mencapai 100\% dari 119 SMP Negeri/Swasta yang tercatat di Kabupaten Ciamis. Berdasarkan data Pusat Penilaian Pendidikan Kementerian Pendidikan dan Kebudayaan bahwa Kabupaten Ciamis memperoleh nilai rata-rata Ujian Nasional 50,30 dan berada di bawah nilai rata-rata Provinsi Jawa Barat yaitu 53,50. Sementara capaian yang didapatkan pada tingkat Provinsi Jawa Barat, Kabupaten Ciamis berada pada posisi urutan 16 dan hal ini masih jauh untuk bisa mencapai target pada urutan 10 besar di provinsi Jawa Barat.

Faktor lain yang mempengaruhi mutu layanan pendidikan adalah dari guru (Madani, 2019). Berdasarkan wawancara awal bahwa guru pada beberapa kepala sekolah sudah berkurang bahkan untuk tahun 2022 banyak guru yang pensiun. Guru merupakan bagian garis terdepan dalam memberikan layanan pendidikan terhadap peserta didik dan paling berpengaruh terhadap keberhasilan pendidikan. Sementara kualitas guru merupakan ujung tombak dari layanan secara langsung untuk menghasilkan siswa berprestasi melalui proses pembelajaran. Salah satu proses pembelajaran yang dilakukan guru adalah persiapan dalam mengajar. Berdasarkan penelitian bahwa persiapan guru adalah salah satu korelasi terkuat dalam prestasi siswa (Darling, 2000). Sementara berdasarkan hasil wawancara awal dengan beberapa kepala sekolah ternyata banyak ditemukan sekolah-sekolah yang kekurangan guru. Jumlah guru yang kurang tentunya akan mempengaruhi terhadap mutu layanan terutama akademik untuk peserta didik.

Tujuan makalah ini adalah untuk mengetahui pengaruh faktor kompetensi manajerial dan kewirausahaan kepala sekolah terhadap mutu layanan akademik serta memberikan gambaran tentang mutu layanan akademik di Sekolah Menengah Pertama Negeri di Kabupaten Ciamis.

\section{KAJIAN TEORITIS}

\section{Peran Kepala Sekolah dalam Mutu Layanan Akademik}

Pendidikan sangat penting dan merupakan fakta yang tidak disangkal. Pentingnya pendidikan tidak akan melihat terhadap agama apapun, ras apapun, suku apapun (Zafar, 2016). Menurut Kotler pada Eres (2013) bahwa layanan merupakan kegiatan yang tidak kasat mata yang mana terdapat manfaat yang dapat diberikan oleh seseorang atau lembaga tertentu. Kualitas layanan menyiratkan perbandingan layanan dan diharapkan sebagai hasil dari penilaian pelanggan terhadap serangkaian faktor layanan (Monferrer, 2019). Kemudian berdasarkan pandangan kelembagaan atau organisasi 
menurut McColl, Callaghan dan Palmer (1998) menyatakan bahwa kualitas layanan adalah penyediaan kondisi yang diperlukan dalam mencapai tujuan dan kualitas organisasi dan tujuan utama adalah kepuasan (Eres, 2013). Bateson dan Hoffman dalam Senoll (2017) menyampaikan bahwa kualitas layanan merupakan penilaian jangka panjang yang dilakukan oleh pelanggan dari proses lembaga.

Menurut Education for All: Global Monitoring Report 2005 - The Quality Imperative (EFA: GMR) dalam Aminuzaman (2015) dinyatakan bahwa terdapat dua prinsip yang menjadi ciri untuk mendefinisikan kualitas dalam pendidikan yang pertama yaitu mengidentifikasi perkembangan kognitif peserta didik sebagai tujuan utama. Yang kedua yaitu peran pendidikan dalam meningkatkan nilai-nilai dan sikap tanggung jawab sebagai warga negara dan memelihara perkembangan kreatif dan emosional. Demirtaş, Z., \& Kahveci, G. pada Senol (2017) menyampaikan bahwa guru akan mencapai kesuksesannya yang tinggi bilamana mereka dapat memenuhi apa yang dibutuhkan oleh masyarakat bahkan melebihi dari harapannya yaitu merubah kemapuan pengetahuan, keterampilan serta sikap siswa. Hoy, Jardine and Wood (2005) berpendapat bahwa istilah mutu dalam pendidikan adalah evaluasi proses mendidik dalam meningkatkan kebutuhan untuk mencapai dan mengembangkan proses bakat peserta didik dan sesuai dengan kebutuhan masyarakat.

Pemerintah menjamin masyarakat pada kualitas layanan pendidikan. Berdasarkan Peraturan Pemerintah Nomor 32 tahun 2013 pada pasal 1 ayat 1 ditegaskan bahwa ruang lingkup standar pemerintah dalam pemenuhan mutu pendidikan yang dikenal dengan 8 standar nasional pendidikan. Standar Nasional Pendidikan tersebut terdiri dari Standar Kelulusan, Standar Isi, Standar Proses, Standar Penilaian, Standar Guru dan Tenaga Kependidikan, Standar Sarana dan Prasarana, Standar Pembiayaan dan Standar Pengelolaan.

Berbicara tentang kualitas pendidikan, kepala sekolah diakui sebagai orang penting yang sangat terlibat dalam meningkatkan kondisi belajar mengajar di sekolah. Namun, relatif sedikit kepala sekolah yang mendedikasikan waktu dan upayanya dalam meningkatkan hasil prestasi siswa (Liebowitz, 2019). Menurut Szell (2013) bahwa terdapat faktor-faktor yang mempengaruhi prestasi siswa atau sekolah adalah siswanya sendiri, faktor sekolah, dan guru. Selain itu, faktor lain yang berpengaruh terhadap prestasi siswa adalah latar bekang keluarga, orientasi keyakinan siswa terhadap pembelajaran, interaksi guru dan siswa, dan konten kurikulumnya (Dukmak, 2015). Menurut Alma dalam Martasubrata (2016) bahwa mutu akademik adalah seperangkat pengetahuan yang dimiliki peserta didik yang dibentuk melalui proses-proses pendidikan manusia serta alat yang dipergunakannya, kurikulum, kualitas yang dimiliki oleh instruktur, guru/dosen, kualitas bahan pembelajaran yang dipergunakan serta kualitas hasil belajarnya.

\section{Layanan Akademik Sekolah}

Kepala sekolah adalah pimpinan tertinggi yang ada di sekolah dimana mereka mempunyai kewenangan dalam memberikan tugas-tugas kepada pendidik dan tenaga kependidikan serta mengelola segala urusan yang ada di sekolahnya. Kepala sekolah diakui sebagai orang penting yang sangat terlibat dalam meningkatkan kondisi belajar mengajar di sekolah. Namun, relatif sedikit kepala sekolah yang mendedikasikan waktu dan upayanya dalam meningkatkan hasil prestasi siswa (Liebowitz, 2019). Menurut Szell (2013) menyatakan bahwa terdapat faktor-faktor yang mempengaruhi terhadap prestasi siswa atau sekolah adalah siswanya sendiri, sekolah dan guru.

Menurut Alma dalam Martasubrata (2016) bahwa mutu akademik adalah seperangkat pengetahuan yang dimiliki peserta didik yang dibentuk melalui proses-proses pendidikan manusia serta alat yang dipergunakannya, kurikulum, kualitas yang dimiliki oleh instruktur, guru/dosen, kualitas bahan pembelajaran yang dipergunakan serta kualitas hasil belajarnya. Sedangkan berdasarkan Repository UPI (2020) disampaikan bahwa layanan akademik adalah layanan bimbingan dan konseling 
yang memandirikan peserta didik dalam kegiatan belajar, meliputi kegiatan tatap muka (pembelajaran di kelas), pengerjaan tugas terstruktur dari guru dan belajar secara mandiri.

Kepala sekolah sebagai seorang pimpinan pada sekolah harus mampu memanfaatkan sumber daya yang ada di sekolahnya secara efektif dalam pemenuhan layanan akademik di sekolahnya. Maka dengan itu dalam memberikan layanan akademik di sekolah perlu mencakup hal-hal sebagai berikut:

1. Kesadaran tentang potensi diri siswa dalam belajar dan memahami berbagai hambatan yang mungkin muncul dalam proses belajar yang dialaminya,

2. Dapat meningkatkan sikap dan kebiasaan siswa dalam belajar yang baik,

3. Menumbuhkan keinginan yang tinggi dalam belajar sepanjang usianya,

4. Menemukan dan memiliki keterampilan belajar yang efektif,

5. Mampu memiliki keterampilan dalam menetapkan tujuan perencanaan pembelajarannya di masa depan,

6. Kesiapan mental dalam menghadapi penilaian atau ulangan-ulangan atau ujian.

\section{Faktor-Faktor yang Mempengaruhi Mutu Layanan}

Mutu merupakan sesuatu yang diinginkan oleh pelanggan dan bukan apa yang terbaik menurut sekolah Sallis (2012). Sarana dan prasarana sekolah, kepemimpinan kepala sekolah, lingkungan pembelajaran di kelas dan sekolah mempunyai pengaruh yang besar dalam mewujudkan pelayanan mutu sekolah yang baik menurut Cohen dalam Pinkus (2009). Sedangkan menurut Sallis (2005) terdapat beberapa indikator penting dalam membentuk sekolah yang berkualitas yaitu 1) high moral values; 2) excellent examination results; 3) the support of parents, business and the local community; 4) plentiful resources; 5) the application of the latest technology; 6) strong and purposeful leadership; 7) the care and concern for pupils and students; 8) a well-balanced and challenging curriculum. Dalam meningkatkan mutu layanan pendidikan pada satuan pendidikan, menurut Sudarwan Danim dalam Moh. Saifulloh (2012 . 207) menyampaikan bahwa jika sebuah institusi pendidikan akan melaksanakan peningkatan mutu pendidikannya maka sekolah harus melibatkan lima faktor minimal yang dominan yaitu kepemimpinan kepala sekolah, guru, siswa, kurikulum, dan jaringan kerja sama. Sementara berkaitan dengan indikator mutu menurut Taylor, West dan Smith dalam Muhammad Fadli (2017) menyebutkan bahwa indikator-indikator tersebut adalah: 1) dukungan orang tua, 2) kualitas pendidik, 3) komitmen peserta didik, 4) kepemimpinan sekolah, 5) kualitas pembelajaran, 6) manajemen sumber daya di sekolah 7) kenyamanan sekolah.

Parasuraman, Zeithaml dan Berry menyusun sepuluh penentu kualitas layanan yang dikelompokkan kembali dalam lima dimensi (Sennol 2017, Nooripoor 2020). Model SERVQUAL adalah lima dimensi yang terkenal tersebut. Lima dimensi tersebut menurutnya terdiri atas kualitas pelayanan yang meliputi penampilan fisik (tangible), keandalan (reliability), daya tanggap (responsiveness), kepastian (assurance), dan empati (empathy). Menurutnya bahwa penampilan fisik (tangible) merujuk terhadap penampilan fasilitas sarana dan prasarana yang dimiliki lembaga pendidikan, para pegawainya yang benar-benar dapat terlihat langsung. Reabilitas mengacu pada keandalan dan akurasi janji atas kemampuan layanan lembaga pendidikan yang dapat diberikan. Kemudian daya tanggap (responsiveness) merupakan kemampuan lembaga pendidikan dalam memberikan kualitas layanan yang cepat. Sementara, Assurance menurutnya bahwa para pegawainya akan memberikan layanan yang baik dan memberikan kepercayaan dan keyakinan kepada pelanggannya. Dan terakhir adalah empathy mengacu terhadap perhatian lembaga pendidikan dalam memberikan perhatian yang baik kepada peserta didik sehingga mereka merasa dihargai. 


\section{Kompetensi Kepemimpinan Kepala Sekolah Kepala Sekolah}

Para ahli banyak memberikan istilah definisi kepemimpinan. Menurut Robbin (2003) bahwa kepemimpinan adalah kemampuan untuk mempengaruhi suatu kelompok ke arah tercapainya tujuan. Kepemimpinan merupakan bagian penting dalam mencapai kualitas sekolah yang diinginkan (Chow \& Learning, 2013). Sekolah akan maju jika memiliki kepala sekolah yang visioner, integritas yang tinggi dalam melakukan peningkatan kualitas, dan kemampuan manajerial yang baik (Krug, 2004). Pemimpin diharapkan menggunakan kepemimpinan sebagai proses untuk memastikan terwujudnya tujuan jangka panjang organisasi terutama dalam lingkungan persaingan yang tidak menentu atau dinamis (Kayebi, 2018). Klingborg (2006) mengatakan bahwa konsep kepemimpinan modern adalah berbeda dengan definisi kepemimpinan tradisional dimana kepemimpinan tradisional yang menitik beratkan pada seorang pemimpin yang berkarismatik.

Kepala sekolah yang menerapkan manajemen sekolah yang efektif berpotensi menghasilkan generasi muda berprestasi (Sunaengsih 2019). Menurut Hallinger dan Walker (2017) dan Walker dan Qian (2018) berpendapat bahwa sebagai pemimpin sekolah, kepala sekolah dianggap sebagai tokoh kunci dalam penerapan kebijakan pemerintah yang efektif (Hou, 2019). Pemimpin diharapkan menggunakan kepemimpinan sebagai proses untuk memastikan tujuan jangka panjang organisasi terwujud (Kayebi, 2018). Kepala Sekolah sebagai pemimpin dapat memusatkan pemikirannya pada masa depan atau apa yang harus dilakukannya untuk masa depan organisasi (Lalonde, 2010). Menurut Leithwood dan Riehl (2003) pada Tobin (2014) menyatakan bahwa pemimpin pendidikan atau kepala sekolah harus membimbing warga sekolahnya melalui tantangan-tantangan yang muncul dari perkembangan globalisasi serta permasalahan lingkungan yang semakin kompleks. Jadi kepemimpinan dipandang sebagai proses pengaruh sedangkan manajemen dipandang sebagai memanfaatkan kontrol (Catano \& Stronge, 2007). Ini sejalan dengan Robbin (2003) bahwa kepemimpinan adalah kemampuan untuk mempengaruhi suatu kelompok ke arah tercapainya tujuan.Leithwood dan Riehl (2003) pada Tobin (2014) mengatakan bahwa pemimpin pendidikan atau kepala sekolah harus membimbing sekolahnya melalui tantangan-tantangan yang muncul dari perkembangan globalisasi serta lingkungan yang semakin kompleks.

Sementara dalam memimpin kepala sekolah mempunyai gayanya sendiri. Gaya kepemimpinan adalah cara umum seorang pemimpin berperilaku terhadap bawahannya untuk mencapai tujuan. Ini adalah sejauh mana seorang pemimpin mendelegasikan wewenangnya (Nazim, 2016). Banyak macamnya gaya kepemimpinan yang sudah teridentifikasi (Kayebi, 2018). Lynch (2018) menyatakan bahwa terdapat empat gaya kepemimpinan utama yang dikenal di lingkungan pendidikan. Keempat tipe kepemimpinan ini terdiri servant leadership, Transactional leadership, emotional leadership, dan transformastional leadership.

\section{Kompetensi Kepala Sekolah}

Kepemimpinan merupakan salah satu bagian yang tidak bisa ditinggalkan dan sangat penting dalam pencapaian sekolah yang berkualitas (Chow \& Learning, 2013). Hallinger dan Walker (2017) dan Walker dan Qian (2018) berpendapat bahwa sebagai pemimpin sekolah, kepala sekolah dianggap sebagai tokoh kunci dalam penerapan kebijakan pemerintah yang efektif (Hou, 2019). Berdasarkan Peraturan Menteri Pendidikan Nomor 13 Tahun 2007 bahwa salah satu kompetensi yang perlu dimiliki adalah kompetensi manajerial dan kewirausahaan. 


\section{Kompetensi Manajerial}

Menurut Aslan (2017) tentang kompetensi manajerial dan pengaruhnya terhadap keterampilan manajemen pada tingkat manajemen yang berbeda dapat bervariasi. Berbagai kajian penelitian menunjukan bahwa keterampilan komunikasi, kerja tim, proaktif, visi, manajemen diri, orientasi hasil, orientasi strategis, ambisi, ketekunan, pengambilan keputusan, pengambilan risiko serta kreativitas merupakan kompetensi yang secara umum dimiliki para pemimpin yang mempunyai kemampuan manajerial yang sukses dan efektif (Punia, 2013). Identifikasi dan pengembangan kompetensi manajerial merupakan bagian penting dari manajemen sumber daya manusia dalam pencapaian tujuan strategis organisasi (Martina, 2012).

\section{Kompetensi Kewirausahaan}

Pada kompetensi ini berdasarkan Peraturan Menteri Pendidikan Nasional Nomor 12 Tahun 2007 memiliki dimensi-dimensi kompetensi yang harus dimiliki Kepala Sekolah. Dimensi Kompetensi Kewirausahaan Kepala Sekolah terdiri dari:

1. Menciptakan inovasi yang berguna bagi pengembangan sekolah.

2. Bekerja keras untuk mencapai keberhasilan sekolah sebagai organisasi pembelajar yang efektif.

3. Memiliki motivasi yang kuat untuk sukses dalam melaksanakan tugas pokok dan fungsinya sebagai pemimpin sekolah.

4. Pantang menyerah dan selalu mencari solusi terbaik dalam menghadapi kendala yang dihadapi sekolah/madrasah.

5. Memiliki naluri kewirausahaan dalam mengelola kegiatan sekolah sebagai sumber belajar peserta didik.

\section{METODE PENELITIAN}

Penelitian menggunakan analisis jalur (Path Analysis). Analisis jalur adalah salah satu teknik dalam penelitian dalam pengembangan regresi liner ganda. Teknik ini digunakan untuk menguji besarnya sumbangan (kontribusi) yang ditunjukkan oleh koefisien jalur dari hubungan kausal antar variabel X1 (Kompetensi Manajerial) dan X2 (Kompetensi Kewirausahaan) serta dampaknya terhadap Y (mutu layanan akademik). Model penelitian seperti pada Gambar 1.

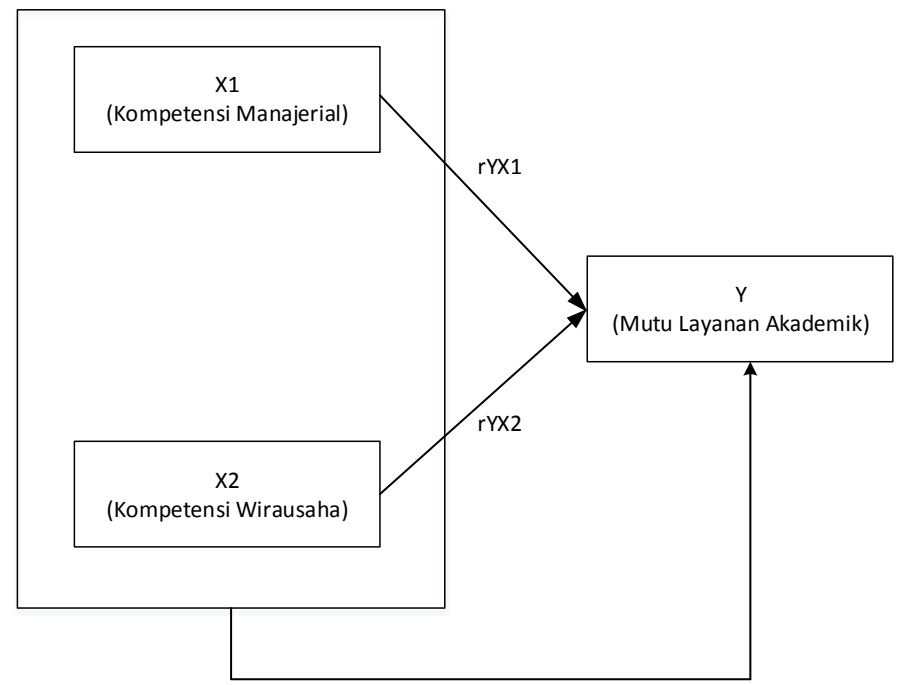

Gambar 1. Variabel penelitian 
Sedangkan formulasi regresi ganda dapat dituliskan sebagai berikut:

$$
\mathrm{Y}=\alpha+\beta 1 \times 1+\beta 2 \times 2+\varepsilon
$$

Untuk pemilihan lokasi penelitian di beberapa sekolah tersebar berdasarkan arah mata angin. Untuk mendukung data responden, peneliti melakukan wawancara kepada Kepala Sekolah, Guru, Komite Sekolah. Menurut Sugiyono (2019) teknik pengambilan sampel dengan probalility sampling. Hal ini dikarenakan jumlah guru tersebar di semua Komisariat dengan jumlah yang jelas. Sampel penelitian terdiri dari 332 guru dari 1.934 guru.

Intrumen dalam skala likert dengan dengan pilihan "Sangat Setuju”, "Setuju", "Ragu", "Tidak Setuju" dan "Sangat Tidak Setuju". Point yang diberikan tersebut adalah 1 sampai dengan 5. Sedangkan data lain diperoleh didapatkan dari hasil wawancara, observasi, dan beberapa studi dokumen.

Untuk validasi hasil outputnya dibandingkan dengan $r$ tabel $\mathrm{df}=\mathrm{n}-\mathrm{k}$ dengan tingkat kesalahan 5\%. Jika r_tabel < r_hitung, maka butir soal disebut valid. Uji reliabilitas dilakukan secara bersamasama terhadap seluruh pertanyaan, jika nilai alpha > 0,05 maka pertanyaan tersebut disebut reliable. Hasil uji reliabilitas intrumen yang telah dilakukan dengan menggunakan uji alpha Cronbach dapat dilihat pada tabel di bawah. Nilai df dalam sampel ini jumlah sampel (30) $-2=28$. R_tabel pada df $=$ 28 pada probabilitas atau nilai $\alpha=0,05$ atau 5\% adalah 0,361 (lihat Tabel $1 \quad$ ). Dari tabel hasil uji reliabilitas, nilai-nilai koefisien reliabilitas pada variabel dependen dan variabel independen memiliki nilai lebih dari r_tabel pada $\alpha=5 \%$. Maka dengan itu bahwa butir pernyataan soal secara keseluruhan adalah reliabel pada $\alpha=5 \%$.

Tabel 1. Hasil uji reliabilitas

\begin{tabular}{ccccc}
\hline Variabel & $\begin{array}{c}\text { Signifikansi } \\
\mathbf{N}=\mathbf{3 0}\end{array}$ & \multicolumn{2}{c}{ Koefisien reabilitas } & Keterangan \\
\cline { 3 - 4 } & $\boldsymbol{\alpha = \mathbf { 0 , 0 5 }}$ & Tahap-1 & Tahap-2 & \\
\hline $\mathrm{X} 1$ & 0,361 & 0,989 & 0,987 & reliabel \\
\hline $\mathrm{X} 2$ & 0,361 & 0,953 & 0,938 & reliabel \\
\hline $\mathrm{Y}$ & 0,361 & 0,978 & 0,974 & reliabel \\
\hline
\end{tabular}

Dalam menentukan validitas nilai-nilai di atas, maka peneliti membandingkan nilai r_hitung dengan $\mathrm{r}$ _tabel pada $\mathrm{df}=\mathrm{N}-2$ yaitu $\mathrm{df}=30-2=28$ dengan probabilitas 0,05 atau 5\%. Dalam penelitian ini uji normalitas yang digunakan adalah dengan menggunakan Kolmogorov-Smirnov. Ketentuan untuk mendapatkan keputusan bahwa data tersebut berdistribusi normal bila nilai sig. $>\alpha=0,05$ dan jika nilai sig. $<\alpha=0,05$ maka data tersebut tidak berdistribusi normal. Berdasarkan hasil analisa statistik Shapiro Wilk dengan menggunakan aplikasi IBM SPSS Stattistics 25 pada $\alpha=0,05$, df $=3$ dengan jumlah populasi (n) adalah 322 didapatkan nilai Asymp sig. adalah 0,083. Dengan melihat ketentuan di atas maka nilai Asymp sig. 0,083 $>\alpha=0,05$ dapat ditarik kesimpulan bahwa data tersebut berdistribusi normal dari hasil uji variabel Layanan Akademik (Y) oleh variabel bebas yaitu Kompetensi Manajerial (X1) dan Kompetensi Kewirausahaan.

Untuk uji linearitas menggunakan pendekatan uji multikolinearitas karena melibatkan lebih dari satu variabel bebas. Berdasarkan ketentuan bahwa jika nilai sig. deviation from linearity $>0,05$ maka terdapat hubungan yang linear antar variabel sebaliknya jika nilai sig. deviation from linearity $<0,05$ maka tidak terdapat hubungan yang linear antar variabel.

Uji homogenitas menggunakan pendekatan heteroskedastisitas. Untuk menentukan tingkat hubungan korelasi variabel, menurut Sugiyono (2019) memberikan tingkat hubungan berdasarkan Tabel 2. 
Tabel 2. Pedoman Interprestasi Koefisien Korelasi

\begin{tabular}{cc}
\hline Interval Koefisien & Tingkat Hubungan \\
\hline $0,00-0,199$ & Sangat rendah \\
$0,20-0,399$ & Rendah \\
$0,40-0,599$ & Sedang \\
$0,60-0,799$ & Kuat \\
$0,80-1,000$ & Sangat Kuat \\
\hline
\end{tabular}

\section{HASIL DAN PEMBAHASAN}

Hasil

Terdapat 1934 populasi guru secara keseluruhan dan berdasarkan hasil perhitungan maka sampel yang didapatkan adalah 322 guru. Sampel data per Komisariat dapat dilihat pada tabel di bawah.

Tabel 3. Jumlah guru pada populasi dan sampel

\begin{tabular}{cccc}
\hline No & Komisariat & Jml Guru & $\begin{array}{c}\text { Sampel guru per } \\
\text { Komisariat }\end{array}$ \\
\hline 1 & Komisariat 1 & 358 & 60 \\
2 & Komisariat 2 & 381 & 63 \\
3 & Komisariat 3 & 309 & 51 \\
4 & Komisariat 4 & 241 & 40 \\
5 & Komisariat 5 & 322 & 54 \\
6 & Komisariat 6 & 323 & 54 \\
\hline & JUMLAH & 1.934 & 322 \\
\hline
\end{tabular}

Dari tabel di atas dapat diketahui sampel terbesar adalah pada Komisariat 2 yaitu sebanyak 63 guru sedangkan sampel terkecil berada di Komisariat 4 sebanyak 40 guru.

Analisis univariabel digunakan untuk mendeskripsikan karakteristik variabel yang diteliti, dalam bentuk tabel distribusi frekuensi. Variabel yang datanya numerik yaitu manajerial dan kewirausahaan digunakan nilai mean, median, standar deviasi serta minimal dan maksimal. Distribusi responden berdasarkan karakteristik variabel yang diteliti pada skala data numerik dapat dilihat pada Tabel 4.

Tabel 4. Distribusi Responden Berdasarkan Karakteristik Variabel (data numerik)

\begin{tabular}{cccccc}
\hline Variabel & Jumlah & Mean & Median & SD & Min - Max \\
\hline Manajerial & 332 & 148,21 & 155,00 & 15,8 & $32-160$ \\
Kewirausahaan & 332 & 27,63 & 29,00 & 3,34 & $6-30$ \\
Layanan Akademik & 332 & 179,33 & 185,00 & 16,48 & $51-195$ \\
\hline
\end{tabular}

Distribusi responden pada tabel Distribusi Responden Berdasarkan Karakteristik Variabel (data numerik) didapatkan rata-rata nilai kepribadian kepala sekolah menurut responden sebesar 55,63 dengan simpangan baku 5,94 nilai tertinggi 60 nilai terendah 20. Nilai rata-rata manajerial kepala sekolah menurut responden 148,21 dengan simpangan baku 15,8 dengan nilai tertingi 160 dan nilai terendah 32. Rata-rata nilai supervisi kepala sekolah menurut responden 27,8 dengan simpangan baku 3,05 dengan nilai tertingi 30 dan nilai terendah 6. Rata-rata nilai layanan akademik kepala sekolah menurut responden 173,33 dengan simpangan baku 16,88 dengan nilai tertingi 51 dan nilai terendah 195. 
Distribusi responden berdasarkan karakteristik variabel yang diteliti pada skala data kategorik dapat dilihat pada Tabel 5.

Tabel 5. Distribusi Responden Berdasarkan Karakteristik Responden

\begin{tabular}{ccc}
\hline Variabel & Jumlah & Persentase \\
\hline Jenis kelamin & 192 & \\
Laki-laki & 140 & 57,80 \\
Perempuan & & 42,20 \\
Status Kepegawaian & 266 & \\
PNS & 66 & 80,10 \\
Non PNS & & 19,90 \\
\hline
\end{tabular}

Distribusi responden berdasarkan tabel 5 paling banyak berjenis kelamin laki-laki yaitu 192 orang $(57,80 \%)$ dan perempuan 140 orang (42,20\%), PNS 266 orang $(80,10 \%)$ dan Non PNS 66 orang $(19,90 \%)$.

Analisis multivariabel digunakan untuk mengetahui pengaruh secara simultan antara variabel bebas dengan variabel terikat dan untuk mengetahui variabel bebas mana yang memiliki pengaruh terhadap variabel terikat. Alat uji yang digunakan regresi linier ganda menggunakan komputer. Variabel yang masuk kandidat multivariabel adalah variabel dengan nilai $p$ value $<0,15$. Hubungan variabel independen skala data numerik terhadap variabel dependen dapat dilihat pada Tabel 6.

Tabel 6. Hubungan Variabel Independen Skala Data Numerik Terhadap Variabel Dependen

\begin{tabular}{ccc}
\hline Variabel & $\mathbf{R}$ & p value \\
\hline Manajerial & 0,864 & 0,000 \\
Kewirausahaan & 0,850 & 0,000 \\
\hline
\end{tabular}

Tabel di atas merupakan hubungan variabel independen terhadap variabel dependen. Variabel manajerial mempunyai korelasi sangat kuat dengan layanan akademik ( $\mathrm{r}=0,864)$ dan berhubungan secara bermakna dengan layanan akademik karena $p$ value 0,000 kurang dari sama dengan $\alpha(0,05)$. Variabel kewirausahaan mempunyai korelasi sangat kuat dengan layanan akademik $(\mathrm{r}=0,850)$ dan berhubungan secara bermakna dengan mutu layanan akademik karena $p$ value 0,008 kurang dari sama dengan $\alpha(0,05)$.

Pengaruh secara simultan antara variabel manajerial dan kewirausahaan terhadap mutu layanan akademik dapat dilihat pada Tabel 7.

Tabel 7. Pengaruh Bersama Variabel Independent Terhadap Variabel Dependen

\begin{tabular}{cccc}
\hline Variabel & $\mathbf{r}$ & r square & p value \\
\hline Konstan & 0,884 & 0,782 & 0,000 \\
\hline
\end{tabular}

Hasil uji statistik pada tabel di atas menunjukan bahwa nilai p sebesar 0,000 jika dibandingkan dengan nilai $\alpha(0,05)$ nilai $\mathrm{p}$ kurang dari $\alpha$, artinya terdapat pengaruh secara simultan antara variabel manajerial dan kewirausahaan terhadap layanan akademik kepala sekolah. Nilai r sebesar 0,884 artinya besarnya pengaruh variabel manajerial dan kewirausahaan terhadap layanan akademik kepala sekolah adalah 88,4\%. Koefisien determinasi ( $r$ square) sebesar 0,782 artinya bahwa kemampuan variabel bebas yaitu variabel manajerial dan kewirausahaan dalam menjelaskan varians layanan akademik kepala sekolah adalah sebesar 78,2\%. Masih terdapat $21,8 \%$ varians variabel terikat yang belum mampu dijelaskan oleh variabel bebas dalam penelitian ini. 
Untuk mengetahui variabel yang paling berpengaruh pada layanan akademik kepala sekolah dilakukan analisis dengan metode backward. Setelah dilakukan seleksi, ternyata variabel yang independen yang masuk model akhir regresi adalah manajerial, supervisi dan kewirausahaan. Hasilnya seperti pada Tabel 8 .

Tabel 8. Pengaruh Variabel Manajerial dan Kewirausahaan Terhadap Variabel Layanan Akademik

\begin{tabular}{lccc} 
Variabel & r & r square & p value \\
Konstan & 0,883 & 0,780 & 0,000 \\
\hline
\end{tabular}

Tabel di atas menunjukan bahwa nilai koefisien determinasi (r square) sebesar 0,780 artinya bahwa model regresi yang diperoleh dapat menjelaskan $78 \%$ variasi variabel layanan akademik kepala sekolah atau dengan kata lain variabel manajerial dan kewirausahaan dapat menjelaskan $78 \%$ variasi variabel layanan akademik kepala sekolah. Hasil uji statistik menunjukan nilai p sebesar 0,000, artinya pada $\alpha(0,05)$ dapat dinyatakan bahwa model regresi cocok (fit) dengan data yang ada, atau dapat juga diartikan bahwa variabel manajerial dan kewirausahaan secara significan dapat digunakan untuk memprediksi variabel layanan akademik kepala sekolah. Model akhir yang diperoleh ditunjukkan pada Tabel 9.

Tabel 9. Model Akhir

\begin{tabular}{ccccc}
\hline No & Variabel & Koef & SE & P value \\
\hline 1. & Konstanta & 46,672 & & 0,000 \\
2. & Manajerial & 0,541 & 0,518 & 0,000 \\
3. & Kewirausahaan & 1,902 & 0,385 & 0,000 \\
\hline
\end{tabular}

Dari tabel di atas maka dapat diperoleh persamaan penelitian sebagai berikut:

\section{Skor Mutu Layanan Akademik = 46,672+ 0,541 manajerial + 1,902 kewirausahaan}

Bila ada seorang responden menyatakan bahwa kemampuan manajerial kepala sekolah 10 dan kemampuan kewirausahaan 10, maka skor layanan akademiknya sebagai berikut adalah sebesar 71,102.

\section{Pembahasan}

\section{Kompetensi Kepala Sekolah}

Kompetensi Manajerial Terhadap Mutu Layanan Pendidikan

Kompetensi manajerial kepala sekolah menunjukan bahwa terdapat pengaruh terhadap layanan akademik berdasarkan hasil analisa data yang telah dilakukan. Hasil penelitian ini sesuai berdasarkan hasil penelitian Marjan (2019). Untuk menjadi seorang kepala sekolah tentu harus mempunyai rencanarencana strategis yang dimiliki untuk organisasi yang dipimpinnya agar sekolah dapat melaksanakan kegiatan organisasinya sesuai dengan rencana kepala sekolah yang dimilikinya terutama dalam mencapai visi, misi serta tujuan organisasi tersebut. Kemampuan kepala sekolah dalam menyusun rencana tentu dipertimbangkan atas sumber daya yang dimiliki pada sekolah yang bersangkutan. Sumber daya warga sekolah, biaya, infrastruktur atau sarana dan prasarana yang dimiliki bahwa kepala sekolah mampu semua itu diberdayakan dengan efektif dan seefisien mungkin.

Sumber daya yang dimiliki oleh organisasi sekolah yang dimanfaatkan dan diberdayakan oleh kepala sekolah merupakan kemampuan seorang kepala sekolah dalam komptensinya sebagai seorang pemimpin dalam manajerial di sekolahnya. Sumber daya yang ada harus benar-benar digunakan dalam setiap perubahan yang ada dalam mengembangkan sekolahnya sehingga dapat meningkatkan mutu 
layanan pendidikan bagi para peserta didik dan dalam hal ini adalah mutu layanan akademiknya. Kemampuan kepala sekolah dalam memanfaatkan suber daya yang ada diuji kemampuannya sehingga semua sumber daya yang dimiliki dapat optimal dipergunakan sesuai dengan fungsinya.

Sementara kepala sekolah diuji kemampuannya dalam pengelolaan kurikulum sekolah. Kurikulum nasional pada setiap sekolah baik pada satu kabupaten kota dengan lainnya pada satu provinsi maupun yang berlainan provinsi tentu sama tetapi untuk muatan lokal ada perbedaan. Perbedaan ini tergantung dari potensi daerah masing-masing baik dilihat dari potensi alam, budaya, maupun geografinya. Sementara meskipun kurikulum secara nasional sama tetapi kemampuan kepala sekolah dalam mengelola di dalamnya belum tentu sama hal ini dikarenakakn kemampuan masingmasing kepala sekolah yang berbeda-beda walaupun pada tempat pelatihan dan instruktur yang sama. Kepala sekolah yang memiliki kemampuan dalam pengelolaan kurikulum sangat diperlukan dalam proses peningkatan mutu layanan akademik. Kemampuan sekolah dalam mengelola kurikulum di dalamnya akan memberikan dampak yang baik bagi kualitas lulusannya sehingga tidak sedikit kepala sekolah yang dipertahankan oleh masyarakat untuk tidak dipindahkan pada saat rotasi kepala sekolah. Kualitas kepala sekolah yang mampu mengelola kurikulum di sekolahnya yang pada akhirnya diharapkan untuk dapat meningkatkan mutu lulusan bagi para peserta didik.

\section{Kompetensi Kewirausahaan Terhadap Mutu Layanan Akademik}

Hasil penelitian menunjukan bahwa kompetensi kewirausahaan kepala sekolah mempengaruhi terhadap mutu layanan pendidikan. Hasil penelitian ini sama dengan hasil penelitian sama dengan penelitian (Wiyatno, 2013). Dari hasil beberapa wawancara dengan kepala sekolah bahwa dalam meningkatkan mutu layanan akademik, Kepala Sekolah tidak berperan langsung terhadap siswa tetapi dengan kemampuan kewirausahaannya kepala sekolah dapat meningkatkan kewirausahaan guru yang nantinya berdampak positif terhadap mutu layanan akademik yang diterima siswa. Hasil ini sesuai dengan penelitian Listiningrum (2020).

Inovasi dalam pengembangan sekolah sangat diperlukan dalam peningkatan mutu layanan akademik. Kerja keras kepala sekolah dalam mencapai kesuksesan pada sekolah yang dipimpinnya merupakan target-target mereka untuk mencapai puncak keberhasilannya. Tidak sedikit mereka selalu melakukan inovasi-inovasi pada sekolahnya dengan menambah berbagai macam sarana dan prasarana yang dapat meningkatkan mutu layanan akademik. Kepala sekolah melalui operator di sekolah berkomunikasi untuk melakukan perbaikan-perbaikan data keberadaan sarana dan prasarana yang dimilikinya untuk mendapatkan berbagai macam bantuan yang diperlukan untuk meningkatkan layanan bagi peserta didik dan kepuasan dirinya dan masyarakat sekitar.

Hasil supervisi yang merupakan informasi yang sangat berguna. Kepala sekolah menggunakan informasi tersebut dalam meningkatkan kualitas guru di sekolah. Kekurangan-kekurangan kompetensi guru dapat ditingkatkan melalui prgram-program pelatihan baik pada tingkat sekolah maupun tingkat kabupaten melalui organisasi profesinya seperti Musyawarah Guru Mata Pelajaran (MGMP) atau bentuk organisasi profesi lain. Kepala sekolah memberikan kesempatan bagi mereka yang ingin mengembangkan diri bahkan kepala sekolah harus mempunyai inovasi dalam meningkatkan kualitas guru.

Kepala sekolah dalam memberikan layanan akademik seperti yang telah disampaikan di atas mulai membidik pada teknologi informasi dan komunikasi. Kemampuan ini dalam rangka mengikuti revolusi industri 4.0 yang didasarkan atas komunikasi melalui jejaring internet dengan data base sebagai dasar mereka membuat keputusan-keputusan manajerial. Usaha kerja keras kepala sekolah perlu diberikan penghargaan yang besar dalam meningkatkan mutu layanan akademik ini. Mereka terkadang bekerja tanpa melihat waktu kerja mereka. Bila mereka mendapatkan informasi mengenai 
hal-hal yang berkaitan dengan pekerjaan mereka, kepala sekolah selalu sedia untuk datang dan melayani terutama dalam peningkatan prestasi siswa.

Usaha-usaha kepala sekolah juga tidak hanya sampai di sana, mereka juga mencoba untuk memperlihatkan dan memasarkan hasilnya ketika menjelang penerimaan siswa baru. Hasil usaha dan berbagai prestasi yang diraih melalui prestasi guru maupun siswa akan diperlihatkan oleh kepala sekolah kepada masyarakat sebagai konsumen penerima manfaat dari jasa yang akan diterima untuk menarik minat anak-anak supaya dapat disekolahkan di sana. Mereka mencoba meyakinkan kepada calon siswa dan masyarakat untuk berusaha agar siswa dapat disekolahkan di sana.

Kerja keras kepala sekolah tentu menjadi sebuah persaingan yang ketat di antara mereka. Sehingga variabel ini tentu menjadi variabel dengan koefisien terbesar dibandingkan dengan variabel lainnya. Prestasi bagi kepala sekolah adalah dimana mereka mampu mengadakan perubahan-perubahan fisik pada sarana dan prasarana dan seringnya berinovasi sehingga memiliki berbagai prestasi baik pada tingkat kabupaten sampai pada tingkat nasional.

\section{KESIMPULAN}

Beberapa kesimpulan dari hasil penelitian ini yaitu:

1. Kompetensi manajerial dan kewirausahaan Kepala Sekolah berpengaruh terhadap mutu layanan pendidikan;

2. Dalam meningkatkan kualitas layanan akademik, Kepala sekolah didukung melalui proses pembelajaran guru di dalam kelas, guru yang berkualitas, dan fasilitas yang memadai terutama dalam meningkatkan prestasi siswa.

3. Proses pembelajaran dan fasilitas yang buruk akan mempengaruhi dampak yang buruk terhadap prestasi siswa.

\section{DAFTAR PUSTAKA}

Aminuzaman S.M., (2015), Research Monograph on: Evaluation of Factors Affecting Quality of Education. A Study on University of Dhaka. Department of Public Administration University of Dhaka. https://www.academia.edu/10873739/Evaluation_of_Factors_affecting_Quality_Education_A_st udy_on_University_of_Dhaka

Aslan M., Pamukçu A. (2017). Managerial competencies and impact on management levels. International Journal of Advanced Research in Management and Social Sciences. Vol. 6 | No. 9: 70-84 | September 2017

Asti Putri K., Udin Syaefudin S. (2015). Kualitas Layanan Akademik Sekolah, Jurnal Administrasi Pendidikan Universitas Indonesia, p.1412-8152 e.2580-1007

Catano, N., \& Stronge, J.H. (2007). What do we expect of school principals? Congruence between principal evaluation and performance standards. International Journal of Leadership in Education, 10(4). 379-399. DOI: 10.1080/13603120701381782

Chow \& Learning, O. (2013). Merging Design Principles, Systemic Change and Leadership Thinking. TechTrends, 57(5)

Creswell J.W. (2009). Research design pendekatan kualitatif, kuantitatif dan mixed, Yogyakarta: Pustaka Pelajar.

Cresswell, J.W. and Clark, V.L.P. (2018) Mendesain dan Melaksanakan Mixed Method Research, Edisi ke-2, Edisi Bahasa Indonesia, Pustaka Belajar.

Darling, L. \& Hammon. (2000). Teacher Quality and Student Achievement: A Review of State Policy Evidence. Education Policy Analysis Archives DOI: 10.14507/epaa.v8n1.2000 
Dukmak, S. (2015). Factors Influencing the Academic Achievement of Students in the Preparatory and Secondary Schools of the United Arab Emirates. European Journal of Social Sciences ISSN 1450-2267 Vol. 46 No 2 January, 2015, pp.132-148

Eres, F., Clothey, R. (2013). Perceived Service Quality in Schools of Education: A Comparative Study between Drexel University and Gazi University. American International Journal of Social Science. Vol. 2 No. 7; October 2013 https://ejournal.upi.edu/index.php/manajerial/article/view/2163/1515

Hafees, S. J.,(2017). Factors Affecting The Quality Of Primary Education In Kerala, Research Scholar, School of Foreign Languages, IGNOU, New Delhi, ISSN NO.:2319-7129, volume 6(1):245, Edu World (2017)

Hoy, C., Jardine, C. B. and Wood, M. (2005). Improving Quality in Education. London and New York: Falmer Press.

Hou, Y., Cui, Y., \& Zhang, D. (2019). Impact of instructional leadership on high school student academic achievement in China. Asia Pacific Education Review (2019) 20:543-558. Education Research Institute, Seoul National University, Seoul, Korea 2019. https://doi.org/10.1007/s12564-019-09574-4

Kayebi, M.J.B. (2018). Transformational Vs Transactional Leadership with Examples. The International Journal of Business \& Management (ISSN 2321-8916). Vol 6 Issue 5. 191-193. https://www.researchgate.net/publication/326832236

Klingborg, D.J., Moore, D.A., Varea-Hammond, S. (2006). What Is Leadership? Article in Journal of Veterinary Medical Education. University of California, Davis. DOI: 10.3138/jvme.33.2.280

Krug, D. H. (2004). Leadership and Research : Reimagining Electronic Technologies for Supporting Learning Through the Visual Arts.Studies in Art. Education a Journal of Issues and Research, 46(1), pp. 3-5

Liebowitz, D.D., Porter, L. (2019). The Effect Of Principal Behaviors On Student, Teacher And School Outcomes: A Systematic Review And Meta-Analysis Of The Empirical Literature. University of Oregon, College of Education. Department of Educational Methodology, Policy and Leadership, Eugene, OR 97403

Listiningrum, H.D., Wisetsri, W., Boussanlegue. T., (2020). Principal's Entrepreneurship Competence in Improving Teacher's Entrepreneurial Skill in High Schools. Journal of Social Work and Science Education. Volume 1 (1) 2020 p. 87-95. E-ISSN: 2723-6919.

Lynch, M. (2016). The Advocate: 4 Major Types of Educational Leadership. https://www.theedadvocate.org/4-major-types-of-educational-leadership/

Madani, R.A. (2019). Analysis of Educational Quality, a Goal of Education for All Policy. Higher Education Studies; Vol. 9, No. 1 p. 100-109. ISSN 1925-4741 E-ISSN 1925-475X. ; 2019. Published by Canadian Center of Science and Education. URL: https://doi.org/10.5539/hes.v9n1p100

Marjan (2019). Pengaruh Kompetensi Manajerial Kepala Sekolah terhadap Peningkatan Mutu Pendidikan di SMPN 3 Sungguminasa. Undergraduate (S1) thesis, Universitas Islam Negeri Alauddin Makassar.

Martasubrata N., Suwatno (2016), Mutu layanan akademik sebagai determinan kepuasan mahasiswa, Jurnal Pendidikan Manajemen Perkantoran, Vol. 1 No. 1, Hal. 136-143.

Martina K., Hana U., Jiří F. (2012), Identification of Managerial Competencies in Knowledge-based Organizations. Journal of Competitiveness. Vol. 4, Issue 1, pp. 129-142, March 2012. ISSN 1804-171X (Print), ISSN 1804-1728 (On-line), DOI: 10.7441/joc.2012.01.10 
Moh. Saifulloh, Muhibin Z., Hermanto, (2012). Strategi Peningkatan Mutu Pendidikan di Sekolah, jsh Jurnal Sosial Humaniora, Vol 5 No.2, November 2012: 206-218.

Monferrer, D. et. All (2019). Service Quality and Customer Loyalty in a Post-Crisis Context. Prediction-Oriented Modeling to Enhance the Particular Importance of a Social and Sustainable Approach. Department of Business Administration and Marketing, Universitat Jaume I, 12071 Castellón, Spain; jsegarra@uji.es (J.R.S.); estrada@uji.es (M.E.); amoliner@uji.es (M.A.M.). Sustainability 2019, 11, 4930; doi:10.3390/su11184930

Muhammad, J., Ghulam M., Muhammad I. (2018). Impact of school infrastructure and pedagogical materials on its academic performance: Evidence from Khyber Pakhtunkhwa, FWU Journal of Social Sciences, Summer 2018, Part-1, Vol.12, No.1, 42-55.

Mulyana, A., (2015). Manajemen Mutu Pendidikan di Sekolah Peran Kepemimpinan Kepala Sekolah, Profesionalisme Guru, dan Partisipasi Masyarakat Dalam Peningkatan Mutu Pendidikan Di Sekolah, Jurnal Penelitian Pendidikan, ISSN 1412-565 X e-ISSN 2541-4135

Nazim, F., Mahmood, A. (2016). Principals' Transformational and Transactional Leadership Style and Job Satisfaction of College Teachers. Journal of Education and Practice www.iiste.org ISSN 2222-1735 (Paper) ISSN 2222-288X (Online) Vol.7, No.34 18 - 22.

Nooripoor, M., Sharifi, Z. (2020) Assessment of the Quality of Academic Services at Yasouj University: Application of SERVQUAL Model. International Journal of Agricultural Management and Development, 10(4), 347-359.

Parasuraman, Valerie A. Zeithaml, and Leonard L. Berry, (1985). A Conceptual Model of Service Quality and Its Implications for Future Research, “ Journal of Marketing (Fall 1985): 41-50. Reprinted by permission of American Marketing Association.

Punia B.K., Bardwaj A. (2013). Managerial competencies and their influence on managerial performance: a literature review. International Journal of Advanced Research in Management and Social Sciences. Vol. 2 No. 5 May 2013 www.garph.co.uk IJARMSS pp 70

Pinkus L.M. (2009). Moving Beyond AYP: High School Performance Indicators. Alliance for Excellent Education. 1-20. http://www.all4ed.org/files/SPIMovingBeyondAYP.pdf

Sallis, E. (2005). Total Quality Management in Education. London: Kogan Page Limited.

Senol, H., Dagli, G. (2017), Increasing Service Quality in Education: Views of Principals and Teachers, Eurasia Journal of Mathematics, Science and Technology Education. 13(8):4857-4871 DOI: 10.12973/eurasia.2017.00969a.

Suhardan, D. (2012). Supervisi Profesional Layanan dalam Meningkatkan Mutu Pembelajaran di Era Otonomi Daerah, Jakarta: Alfabeta.

Sugiyono (2019). Metode Penelitian Pendidikan (Kuantitatif, Kualitatif, R\&D, dan Penelitian Pendidikan), Penebit Alfabeta, Bandung.

Szell, K. (2013). Factors Determining Student Achievement. Hungarian Educational Research Journal. 2013, Vol. 3(3) 55-66. DOI: 10.14413/HERJ2013.03.06.

Taylor, M. J., West, R. P dan Smith, T. G. (2016). Indicator of School Quality. John (http://www.csf.usu.edu/) diakses pada Maret 2016.

Tobin, J. (2014) Management and Leadership Issues for School Building Leaders. NCPEA International Journal of Educational Leadership Preparation, Vol. 9, No. 1 - March, 2014. National Council of Professors of Educational Administration

Wiyatno, M. (2013). Peran Kompetensi Kewirausahaan Kepala Sekolah Dalam Peningkatan Mutu Pendidikan di SMP N 3 Jetis, Bantul. Jurnal Akuntabilitas Manajemen Pendidikan 1(1):162-174.

DOI: $\underline{10.21831 / a m p . v 1 i 1.2338}$ 